\title{
Relationship between antigen concentration and bacterial load in Pacific salmon with bacterial kidney disease
}

\author{
Owen S. Hamel* James J. Anderson \\ Columbia Basin Research, School of Aquatic and Fisheries Sciences, PO Box 358218, University of Washington, Seattle, \\ Washington 98195, USA
}

\begin{abstract}
Using data collected to test spawning female Pacific salmon (Oncorhynchus kisutch and O. tshawytscha for the presence and severity of bacterial kidney disease (BKD), a mathematical model of the relationship between bacterial load and antigen concentration in tissues and ovarian fluid is developed. Renibacterium salmoninarum, the causative agent of BKD, secretes large amounts of a $57 \mathrm{kDa}$ protein ('p57'), its major soluble antigen, which eventually breaks down or is otherwise removed from free circulation. Bacterial load and soluble antigen concentration in tissues are strong indicators of fish health, while in ovarian fluid they are predictors of the success of offspring. Model results indicate either an exponentially increasing antigen removal rate or an exponentially decreasing per-bacterium antigen secretion rate with increasing antigen concentration. Possible mechanisms underlying the observed relationship include a nonlinear increasing autolytic rate of the 'p57' antigen and a bacterium-antigen interaction threshold which prevents bacterial antigen secretion.
\end{abstract}

KEY WORDS: BKD ·p57 · Mathematical model $\cdot$ Spawning female Pacific salmon $\cdot$ Bacteria $\cdot$ Antigen

Resale or republication not permitted without written consent of the publisher

\section{INTRODUCTION}

Renibacterium salmoninarum is the causative agent of bacterial kidney disease (BKD), one of the most problematic diseases of farmed, hatchery-reared and wild salmonids worldwide (Fryer \& Sanders 1981). Particularities of $R$. salmoninarum and a $57 \mathrm{kDa}$ surface antigen ('p57') that it secretes in large amounts make the bacterium highly successful in surviving from generation to generation and there is, in fact, no consistent method for the control of BKD (Elliott et al. 1989). $R$. salmoninarum is an obligate salmonid pathogen (Evenden et al. 1993) which reproduces very slowly with a generation time approximating $1 \mathrm{~d}$. Mortality due to BKD often occurs months or even years after initial infection, making it difficult to quantify its effect on salmonid populations.

*E-mail: owen@cbr.washington.edu
The p57 antigen is the major soluble antigen of Renibacterium salmoninarum (Weins \& Kaattari 1999) and may be present in high concentrations in tissues and fluids of infected salmon (Evenden et al. 1993). The concentration of soluble antigen may be an important virulence factor, as the p57 antigen (the principle component of the soluble antigenic fraction) has immunosuppressive and tissue destructive properties, is known to agglutinate salmon leukocytes (Weins et al. 1999), suppress antibody production against unrelated antigens in vitro (Turaga et al. 1987), inhibit phagocyte respiratory burst response at high concentrations, and has been shown to decrease the bactericidal activity of juvenile chinook salmon Oncorhynchus tshawytscha macrophages against Aeromonas salmonicida, an unrelated pathogen (Siegel \& Congleton 1997). Antibody-p57 complexes may remain in tissue and contribute to tissuedestructive hypersensitivity and granulomas (Bruno 1986). 
The p57 antigen is capable of agglutinating leukocytes whether in soluble form or attached to the bacterium (Weins \& Kaattari 1999). Cell-surface associated p57 appears to be an important factor in horizontal transmission, as surface attachment is an important step before entry into host cells. Cell-surface associated p57 may be the major factor inducing uptake of the bacterium by gill tissue and, as Renibacterium salmoninarum can survive ingestion, the lining of the gastro-intestinal tract (Evelyn 1996, Flaño et al. 1996). Ingestion of bacteria-laden feces during feeding is an important route of transmission in farmed salmon (Balfry et al. 1996). Cell-surface associated p57 may also be important in inducing the uptake of $R$. salmoninarum into eggs from the surrounding ovarian fluid before spawning, thus making BKD a rare bacterial disease that can be transmitted vertically from female spawner to offspring (Evelyn et al. 1984, 1986). Brown et al. (1996) suggested that the p57 antigen in soluble form may be taken up by eggs from ovarian fluid, resulting in the subsequent offspring being immunotolerant of p57 and much less capable of resisting R. salmoninarum infections.

Senson \& Stevenson (1999) suggested that p57 and its breakdown products may form a protective layer (or capsule) around Renibacterium salmoninarum cells. Woods \& Kaattari (1996) showed that R. salmoninarum cells stripped of p57 will induce a much stronger immune response than those not stripped of p57. Cellsurface associated p57 and its breakdown products may, then, effectively block highly immunogenic areas of the cell surface from detection by host defenses.

Studies of a virulence-attenuated strain of Renibacterium salmoninarum found it to produce similar amounts of free p57, but less cell-surface-associated p57 than virulent strains of the bacterium (O'Farrell \& Strom 1999, Senson \& Stevenson 1999). The p57 from the virulence-attenuated strain was unable to restore haemagglutination activity to either the attenuated or a virulent strain of $R$. salmoninarum, whereas p57 from a virulent strain of $R$. salmoninarum was able to reassociate with and restore haemagglutination activity to both the attenuated and the virulent strain (Senson \& Stevenson 1999). Chinook salmon Oncorhynchus tshawytscha injected with a high dose $\left(10^{6}\right.$ bacteria fish $^{-1}$ ) of attenuated R. salmoninarum experienced no evident kidney damage and much reduced mortality compared to chinook injected with the same dose of virulent $R$. salmoninarum (O'Farrell et al. 2000). The differences in virulence may be due in part to differences in the molecular structure of the p57 antigen produced by the attenuated strain (Senson \& Stevenson 1999).

The lack of observed differences in free p57 antigen concentration between virulent and attenuated strains of Renibacterium salmoninarum does not indicate that free p57 is not a major virulence factor. Rather, the finding that the p57 from an attenuated strain of $R$. salmoninarum does not appear to attach to the surface of $R$. salmoninarum cells supports the suggestion that one of the functions of p57 in virulent strains is to encapsulate $R$. salmoninarum cells and shield the cell surface from the host immune system. For most naturally occurring strains of $R$. salmoninarum, high concentrations of free p57 should indicate high levels of surface associated p57.

Renibacterium salmoninarum bacteria produce large amounts of p57 (Weins \& Kaattari 1999), both in serum and while in intracellular residence. The p57 antigen may then break down through autolysis (Griffiths \& Lynch 1991), be taken up by antibodies (Bruno 1986) or possibly be absorbed onto or into cells (as suggested by its agglutinating properties) or flushed out of the body.

These studies taken together indicate that the p57 antigen is a significant factor in the transmission and virulence of Renibacterium salmoninarum. Soluble antigen concentration is a quantifiable surrogate for p57 concentration. However, the relationship between bacterial load and soluble antigen concentration in vivo has yet to be quantified. In this paper, we analyze their relationship in tissues and fluids and propose mechanisms that might underlie these observed relationships.

\section{MATERIALS AND METHODS}

To explore the relationship between the bacterial load $B$ and the antigen concentration in solution $A_{\mathrm{s}}$ we consider data from 2 rapid and sensitive methods of quantifying these in salmon. To characterize the bacterial load, bacteria are tagged with a fluorescent antibody and counted under a microscope. For tissue samples this is reported as the number of bacteria per 100 microscope fields of a tissue smear. For ovarian fluid, the reported value is the number per $\mathrm{ml}$ of fluid (Elliott \& Barila 1987). This is known as the fluorescent antibody technique (FAT). The antigen concentration is enumerated with an enzyme-linked immunosorbent assay known as the ELISA test (Pascho \& Mulcahy 1987) which detects soluble antigen levels. The ELISA test optical density $E$ is related to the antigen concentration in solution ( $\left.\mu \mathrm{g} \mathrm{ml}^{-1}\right) A_{\mathrm{s}}$ and roughly fits the relationship:

$$
E=a+b \log A_{\mathrm{s}}
$$

where $a$ and $b$ are calibration factors that may depend on whether the sample is from a tissue or fluid and the specific characteristics of the ELISA test itself. This holds for $A_{\mathrm{s}}$ larger than the minimum level of de- 
tectability. Eq. (1) can be rearranged to calculate $A_{\mathrm{s}}$ given $E$ :

$$
A_{\mathrm{s}}=10^{\frac{E-a}{b}}
$$

Few studies directly relate bacterial load to antigen level so we combined 3 studies that characterized bacterial load using the same FAT methods (Table 1). In each study an antigen surrogate measure $E_{i}$ was derived using the ELISA method. We use the subscript $i$ to designate a particular ELISA test with its specific calibrations. The relationship of $E_{i}$ to $A_{\mathrm{s}}$ varies among the studies.

In a 1987 paper, Pascho et al. (1987) tested samples of kidney and spleen tissue, ovarian fluid and blood from 56 sexually mature female coho salmon Oncorhynchus kisutch for Renibacterium salmoninarum using the ELISA test to derive the surrogate of antigen enumeration, which we designate here $E_{0}$, and the direct or direct filtration FAT test to enumerate bacterial load B. In a 1991 paper, Pascho et al. (1991) tested samples of kidney tissue and ovarian fluid from 30 highly infected sexually mature female chinook salmon $O$. tshawytscha at Dworshak National Fish Hatchery, Idaho (United States Fish and Wildlife Service) for $R$. salmoninarum, enumerating bacterial load $B$ with the FAT tests and the antigen surrogate with the ELISA test. However, the calibration was different from that seen in the 1987 paper, and we designate the results from this test as $E_{1}$. Pascho et al. (1991) also employed a more sensitive test, the ELISA II. We designate the results from this test as $E_{2}$. In the 1991 study, kidney bacterial load values denoted 'Too numerous to count' were assigned the value B = 200000 for our analysis. In a 1998 paper, Pascho et al. (1998) sampled ovarian fluid from 103 spring chinook salmon O. tshawytscha from Carson National Fish Hatchery. Bacterial load $B$ was determined with the membrane-filtration FAT method and the antigen surrogate was determined with the ELISA II method. We designate these values as $E_{2}$ as well. The data used below include the 37 samples for which the FAT enumeration showed a bacterial load of more than 10 thousand $\left(10^{4}\right)$ bacteria $\mathrm{ml}^{-1}$.

Most salmon in the 1991 and 1998 papers were injected with erythromycin at some point before the tissue and fluid sample collection. Consequentially, compared to the first study, a higher proportion of the bacteria enumerated with the FAT tests were expected to be dead or dying. A number of factors reduce the importance of this fact. First, in our analysis we use the logarithm of bacterial load, so even if half the bacteria were dead, the difference in the $\log _{10}$ (bacterial load) would only be 0.3 . Secondly, since nearly all of the fish in these 2 studies were injected, similar effects are seen in all fish within each study, so that the nature of the relationship should not change. Thirdly, given the long residence time of soluble antigen (Pascho et al. 1997), a significant proportion of the antigen originating from the dead bacteria would likely still be in the tissue or fluid sampled.

Similarly, the use of 2 Pacific salmon species (Oncorhynchus kisutch and O. tshawytscha) with possibly different susceptibilities and responses to the disease is not expected to significantly affect the relationship between the bacteria and the antigen. In our model analysis we consider how the host response may affect the antigen/bacterial dynamics.

\section{RESULTS}

\section{ELISA-antigen relationships}

In the combined studies, we have a number of measures of antigen surrogate $E_{i}$ and corresponding bacterial loads $B$. Our analysis has 4 steps: first, we use the analysis provided by Pascho \& Mulcahy (1987) to relate antigen concentration in solution $A_{\mathrm{s}}$ to $E_{0}$; second, we use the limited data and reasonable assumptions on how antigen levels relate to ELISA values in each of the 3 data sets; third, we solve the systems of equations to yield relationships between each of the $E_{i}$ and $A_{\mathrm{s}}$ in the form of Eq. (1) and Eq. (2); fourth, the estimated $A_{\mathrm{s}}$ values are converted to original antigen concentrations $A$ by multiplying by the appropriate dilution factor and these $A$ values are plotted against $B$ to reveal the relationship between antigen concentration and bacterial load.

We estimated the relationship of $A_{\mathrm{s}}$ to $E_{0}$ using data from the second figure in Pascho \& Mulcahy (1987). The relationship is:

$$
E_{0}=a_{0}+b_{0} \log A_{\mathrm{s}}
$$

Table 1. Summary of the 3 data sets from studies characterizing bacterial load using FAT

\begin{tabular}{|lccccc|}
\hline Data set & Species & ELISA test & Kidney tissue & Spleen tissue & Ovarian Fluid \\
\hline Pascho et al. (1987) & Coho & I & $\sqrt{ }$ & $\sqrt{ }$ \\
Pascho et al. (1991) & Chinook & I(\&II) & $\sqrt{ }$ & 36 \\
Pascho et al. (1998) & Chinook & II & & $\sqrt{ }$ & 37 (of 103) \\
\hline
\end{tabular}


Table 2. Data used to create equations relating ELISA values $\left(E_{0}, E_{1}\right.$, or $\left.E_{2}\right)$ to antigen concentrations $(A)$, and the values of $a_{i}$ and $b_{i}$ for each $E_{i}$

\begin{tabular}{|lccccccc|}
\hline Data set & $\begin{array}{c}\text { ELISA } \\
\text { test }\end{array}$ & Symbol & $\begin{array}{c}\text { Data used for } \\
\text { calculations }\end{array}$ & \pm cutoff & $\begin{array}{c}\text { Minimum } \\
\text { value }\end{array}$ & $\begin{array}{c}\text { Maximum } \\
\text { value }\end{array}$ & $\begin{array}{c}\text { Parameters used } \\
\text { for Eq. (1) } \\
a_{i}\end{array}$ \\
\hline 1987 & I & $E_{0}$ & Tissue data & 0.066 & & 1.000 & 0.50 \\
1991 & I \\
1991 & I \\
1991 & II & $E_{1}$ & & 0.058 & & 0.749 & 0.40 \\
1998 & II
\end{tabular}

with $a_{0}$ and $b_{0}$ given in Table 2 . This relationship holds for $A_{\mathrm{s}}>8.25 \times 10^{-2} \mathrm{mg} \mathrm{ml}^{-1}$, which corresponds to the positive/negative $( \pm)$ threshold value of $E_{0}=0.066$. For antigen concentrations below this level, the ELISA values are indistinguishable from the control solution values. Given $E_{0}$, the antigen concentration in solution can be expressed as:

$$
A_{\mathrm{S}}=10^{\frac{E_{0}-a_{0}}{b_{0}}}
$$

The 1987 study (Pascho et al. 1987) was conducted at the same laboratory and near the same time as the calibration between $A_{\mathrm{s}}$ and $E_{0}$ given in Eq. (3). The positive-negative cutoff value of the ELISA in this study was 0.066, which is the same value in Pascho \& Mulcahy (1987). Also, in this study day to day corrections were made in the ELISA values using a statistical technique developed by the authors (Pascho et al. 1987). We assume that the ELISA tests had the same relationship to antigen levels for the data reported in both 1987 papers so both ELISA tests are designated $E_{0}$.

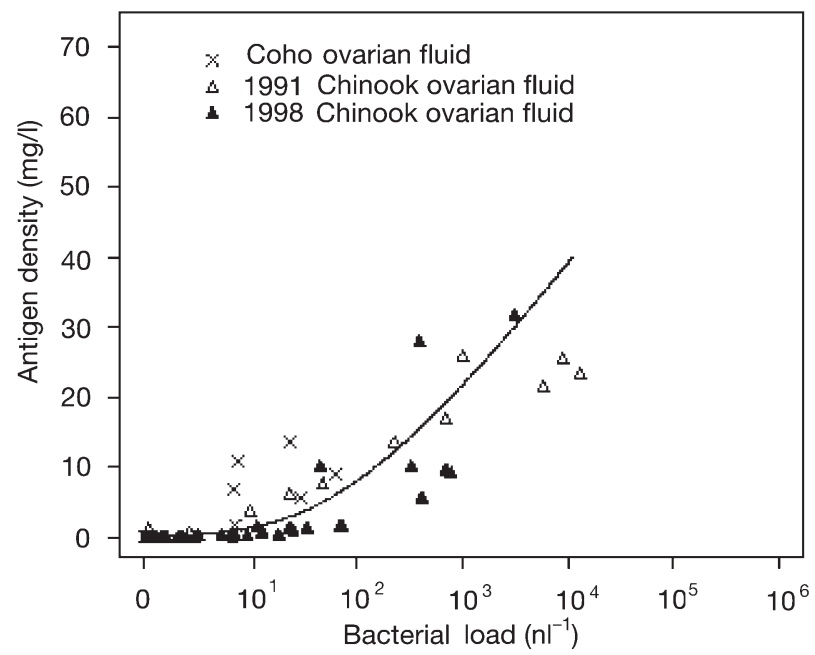

Fig. 1. Antigen concentration vs bacterial load (on a logarithmic scale) and modeled antigen concentration to bacterial load curve for ovarian fluid data
A relationship between $E_{1}$ and $E_{0}$ was derived with 2 assumptions. First, we assume that the positivenegative threshold ELISA values from the 1987 and 1991 tissue data sets represent the same antigen density. Second, we assume equivalent maximum antigen concentrations for these 2 data sets. This second assumption is based on the fact that the maximum countable bacterial loads are similar in the 2 data sets and therefore the logarithm of the maximum bacterial loads are even more similar. Furthermore, this assumption gives nearly the same result as matching up the antigen levels over a range of high bacterial levels. The tissue data sets were used because no positivenegative threshold (denoted \pm below) was noted for the 1987 ovarian fluid data. Given these 2 equivalent values, we can calculate the antigen levels in question using the relationship between $E_{0}$ and $A_{\mathrm{s}}$ previously found. Next, we formulate a system of 2 equations and 2 unknowns:

$$
\begin{aligned}
E_{1( \pm)} & =a_{1}+b_{1} \log A_{\mathrm{s} 1( \pm)} \\
E_{1(\max )} & =a_{1}+b_{1} \log A_{\mathrm{s} 1(\max )}
\end{aligned}
$$

$a_{1}$ and $b_{1}$ can be found by solving this simple system of equations. The results are summarized in Table 2 .

For the 1991 data set, the minimum and maximum values of the ELISA I and ELISA II values for both tissue and ovarian fluid samples are given by Pascho et al. (1991). Since the tests were performed on samples from the same set of fish, the antigen concentrations represented by the ELISA I and ELISA II tests should be the same. The authors were unable to provide the entire set of ELISA II data, so no regression or similar analysis of the relationship between the ELISA I and ELISA II tests could be performed. Instead, we matched the average minimum and maximum ELISA I $\left(E_{1}\right)$ and ELISA II $\left(E_{2}\right)$ values from the tissue and ovarian fluid samples to create a system of 2 equations and 2 unknowns:

$$
\begin{aligned}
& E_{2(\min )}=a_{2}+b_{2} \log A_{\mathrm{s} 2(\min )} \\
& E_{2(\max )}=a_{2}+b_{2} \log A_{\mathrm{s} 2(\max )}
\end{aligned}
$$




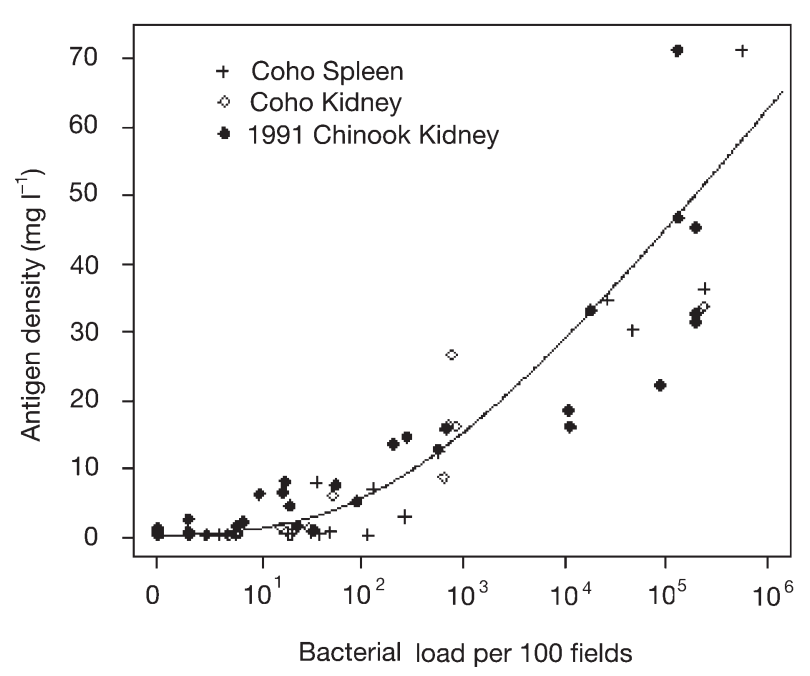

Fig. 2. Antigen concentration vs bacterial load (on a logarithmic scale) and modeled antigen concentration to bacterial load curve for tissue data

The solution of the equations provides the coefficients $a_{2}$ and $b_{2}$ which are then used to translate the 1998 ELISA II data into antigen concentrations in solution $\left(A_{\mathrm{s}}\right)$. The data which provide the basis for these transformations and the resulting $a_{i}$ and $b_{i}$ are given in Table 2 .

In the above analysis, we assumed the same relationships between the $E_{i}$ and $A_{\mathrm{s}}$ in both tissue and fluid samples. While this assumption may be faulty, the tissue and fluid data is considered separately and any error will not affect the nature of the relationship found between bacterial load and antigen concentration.

\section{Bacterial load-antigen concentration relationship}

The relationship between antigen concentration and bacterial load was explored after converting the ELISA values into antigen concentrations. The ELISA values were translated into antigen concentration in solution $\left(A_{\mathrm{s}}\right)$ via Eq. (2). Antigen concentration in tissues and fluids $(A)$ was then back-calculated from concentration in solution by multiplying $A_{\mathrm{s}}$ by the dilution factors: 4 for tissue samples and 2 for ovarian fluid samples.

Given that most ovarian fluid samples with less than $10^{6}$ cells $\mathrm{ml}^{-1}$ via FAT were negative for antigen via ELISA, a new measure of ovarian fluid bacterial load was adopted: cells per nanoliter (cells $\mathrm{nl}^{-1}$ ), found by dividing cells $\mathrm{ml}^{-1}$ by $10^{6}$. For tissues, the FAT enumeration represents number per 100 fields and thus gives only a relative measure of bacterial load.
The bacterial load to antigen concentration relationship was modeled applying basic assumptions about their relative dynamics. The observed antigen concentration was assumed to represent the equilibrium state and this was assumed to be related to the per-bacterium rate of antigen production and the rate of antigen breakdown and removal.

It is clear from the plots of antigen concentration versus bacterial load (Figs. 1 \& 2) that antigen concentration is not linearly related to bacterial load but increases roughly linearly with the logarithm of bacterial load. This relationship can arise either from an increasing rate of antigen breakdown and removal, a decreasing rate of antigen secretion, or a combination of the 2 with increasing bacterial load. In Appendix 1 we show that these assumptions lead to the equation:

$$
\frac{\mathrm{d} A}{\mathrm{~d} t}=a B \mathrm{e}^{-r_{1} A}-b A^{p} \mathrm{e}^{r_{2} A}
$$

with equilibrium solution:

$$
B=k A^{p} \mathrm{e}^{r A}
$$

where $r=r_{1}+r_{2}$ and $k$ is a constant, or, equivalently:

$$
\ln B=r A+p \ln A+\mathrm{C}
$$

where $c=\ln (k)$, or, as the data are in logarithm base 10:

$$
\log B=r^{\prime} A+p \log A+C^{\prime}
$$

where $r^{\prime}=r \times \log _{10}(\mathrm{e})$ and $c^{\prime}=\log _{10}(k)$.

Curves were fit to the data via regression assuming the relationship given in Eqs. (9) \& (10) and using the cells $\mathrm{nl}^{-1}$ form of the ovarian fluid bacterial load data. The results are shown in Fig. 2 \& Table 3.

In the regression results for both tissues and fluids, $p$, the exponent of $A$ in Eq. 8, has a value near 1. This indicates either simple mass action removal of antigen with no significant autolysis or that the autolysis is subsumed in the exponential term. The coefficient of $A$ in the exponential, $r$, is near 0.10 in both cases, and $C$ is near 1.8 (Table 3). The correspondence in the values of $C$ has no meaning, as the value of $C$ for ovarian fluid depends upon the choice of units, here cells $\mathrm{nl}^{-1}$. The close values of the other 2 parameters $(r$ and $p$ ), however, suggest similar processes in both cases with identical multiplicative changes in bacterial load effecting

Table 3. Results of regressions based on Eqs. (9) \& (10). Parameters for the bacterial load to antigen concentration relationship are given for both the natural logarithm and logarithm base 10 forms of the equation

\begin{tabular}{|lcccccccc|}
\hline Data sets & $\mathrm{p}$ & $r^{\prime}$ & $r$ & $c^{\prime}$ & $c$ & $k$ & $\mathrm{R}^{2}$ & $\mathrm{n}$ \\
\hline Tissues & 1.282 & 0.0470 & 0.108 & 0.767 & 1.77 & 5.85 & 0.89 & 142 \\
Fluids & 0.953 & 0.0433 & 0.100 & 0.791 & 1.82 & 6.17 & 0.87 & 123 \\
\hline
\end{tabular}


similar increases in antigen concentration. However, the approximations used above and the differences in detectability of antigen in fluids and tissues preclude any firm statement about the similarity of the process in these 2 differing media.

Ignoring for a moment the above caveat and using the results above, the following equation closely fits the observed equilibrium relationships:

$$
B=k A \mathrm{e}^{r A} \cong 6 A \mathrm{e}^{0.1 A}
$$

The change in the equilibrium value of antigen concentration with bacterial load becomes:

$$
\frac{\mathrm{d} A}{\mathrm{~d} B}=\frac{1}{k \mathrm{e}^{\mathrm{r} A}+r k A \mathrm{e}^{r A}}=\frac{A}{B+r A B}=\frac{A}{B+0.1 A B}=\frac{10 A}{(A+10) B}
$$

This can be approximated when $A$ is small $(A \ll 10 \mathrm{mg}$ $\mathrm{ml}^{-1}$ ) by:

$$
\frac{\mathrm{d} A}{\mathrm{~d} B} \cong \frac{A}{B}
$$

and when $A$ is large $(A \gg 10)$ by:

$$
\frac{\mathrm{d} A}{\mathrm{~d} B} \cong \frac{10}{B}
$$

which means that in the limit:

$$
A \cong 10 \times \ln B+C_{1} \cong 23 \times \log B+C_{2}
$$

This indicates that in the limit (as $A$ and $B$ get large) antigen concentration increases by about 20 to $25 \mathrm{mg}$ $\mathrm{ml}^{-1}$ for each 10 -fold increase in bacterial load. This value should be taken as a first approximation, given the uncertainly in the transformations and the variability of the data.

\section{DISCUSSION}

From data collected to test spawning female Pacific salmon for presence and severity of BKD, a model of the relationship between bacterial load and antigen concentration in tissues and fluids has been developed in this paper. Strong relationships within tissues and fluids were found between the calculated antigen concentrations and bacterial loads.

The measure of bacterial load used in this paper differ between tissues and ovarian fluid. For ovarian fluid the measure is cells $\mathrm{ml}^{-1}$ or cells $\mathrm{nl}^{-1}$. For tissues the measure is cells per 100 fields. While the relationships found between bacterial load and antigen concentration are similar in tissues and fluids, there is no a priori reason to believe the relationship should be the same.

Antigen concentration does not increase linearly with bacterial load, nor is there an evident maximum antigen concentration. The dynamics are complex, due to a number of factors. Turaga et al. (1987) noted that up to $1 \mathrm{mg} \mathrm{ml}^{-1}$ of the p57 antigen and its breakdown products have been found in tissues of severely infected fish. The concentrations of soluble antigen calculated here were far less than $1 \mathrm{mg} \mathrm{ml}^{-1}$. There is evidence that p57 is autolytic (Griffith \& Lynch 1991, Pascho et al. 1998), yet p57 was found to persist for more than 3 mo in tissues of rainbow trout held at $12^{\circ} \mathrm{C}$ (Pascho et al. 1997). The breakdown of p57 is accelerated at higher temperatures (Griffiths \& Lynch 1991), so the relationship between bacterial load and antigen concentration may change with environmental temperature. Temperature may also have significant impacts upon the efficacy of the immune response (e.g. Sanders et al. 1978) and upon bacterial growth rate, and thus the entire dynamics become more complicated when temperature is allowed to vary. Differences in environmental temperature may account for some of the observed differences between data sets.

The mathematical model developed above indicates that antigen concentration increases ever more slowly with increasing bacterial load, so that, in the limit, antigen concentration increases by no more than about $23 \mathrm{mg} \mathrm{ml}^{-1}$ for every 10 -fold increase in bacterial load. The exact value of this upper limit is questionable due to multiple approximations within the analysis, and may, in fact, vary among species, experiments, and the tissue or fluid examined. However, the model and data strongly suggest that antigen concentration per bacterium decreases exponentially with increasing antigen concentration. A number of mechanisms may control this relationship. An exponential increase in antigen breakdown and removal or an exponential decrease in per bacterium antigen secretion with antigen concentration could account for the observed relationship. The evidence of p57 autolysis noted above along with an expected increasing antibody production with increasing infection levels supports the possibility of a non-linearly increasing rate of breakdown and removal of antigen with antigen concentration. Simple mass action could result in a power function in antigen concentration, though not an exponential function, to describe antigen removal. Equally compelling is the possibility that the bacteria reduce their production of antigen, thus saving the metabolic cost of such production, when concentrations of free antigen are high.

One possible mechanism to explain a decreasing antigen secretion rate with increasing antigen concentration is that an individual bacterium secretes the p57 antigen if and only if it has not interacted with a free p57 antigen molecule over a particular period of time. Assuming complete mixing, the number of interactions of any individual bacterium with free antigen over that time period can be modeled as a Poisson process with 
the mean $\lambda=r A$, with the probability of any individual bacterium having zero interactions over that time period being $\mathrm{e}^{-r A}$. Another possible mechanism is that an individual bacterium secretes the p57 antigen if and only if it has at least 1 surface attachment site free of the p57 molecule or 1 of its breakdown products. The mean time that any such site is open would be expected to depend inversely upon the antigen concentration. This mechanism is reasonable if the bacterium produces the p57 antigen in order to protect itself from outside harm, including the immune system. This is directly in line with the suggestion by Senson \& Stevenson (1999) that the p57 antigen and its breakdown products form a protective capsule around the bacterium.

While the mechanistic basis of the relationship between observed bacterial load and observed antigen concentration is not certain, this paper provides a framework in which to relate the 2 factors. The relationship should be useful in management of the disease since antigen concentration in tissues may be of as much importance as bacterial load in determining the efficacy of immune response, and antigen concentration in ovarian fluid is likely the prime predictor of immunotolerance in offspring. Ultimately, knowledge of the mechanisms regulating antigen concentrations and a further clarification of their relationship to bacterial load are likely to be important for the management of the disease. Consequentially, we encourage researchers to report estimated antigen concentrations as well as ELISA values for each sample so a better understanding and parameterization of the relationship can be developed. Furthermore, we believe that research focused on clarifying the mechanisms of antigen secretion and breakdown may be useful in understanding and possibly controlling bacterial kidney disease.

Appendix 1. Development of antigen concentration differential equation

The relationship between soluble antigen concentration and bacterial load is controlled by rates of secretion and removal of antigen through breakdown or excretion. Given the slow dynamics of bacterial growth, we assume the observed relationship represents the equilibrium of a differential equation relating the change in antigen concentration over time given bacterial load and antigen concentration. It is clear from the graphs of antigen concentration versus bacterial load that this relationship is not linear. Nor can Michaelis-Menten dynamics, with the antigen acting as the catalyst in its own breakdown, achieve the observed relationship. Equations of the following form were considered:

$$
\frac{\mathrm{d} A}{\mathrm{~d} t}=f(A) B-g(A)
$$

where $A$ represents antigen concentration, $B$ represents bacterial load and $f(A)$ and $g(A)$ are functions of $A$. In Eq. (A1) both bacterial secretion of antigen and removal of antigen may depend on antigen concentration. Assuming that the antigen concentration is in equilibrium with a given bacterial level and noting that the observed relationship of antigen to bacteria has the form:

$$
A=C_{1} \ln B+C_{2}
$$

then:

$$
B-\alpha \mathrm{e}^{r A}=0
$$

where $r=c_{1}^{-1}$ and $\alpha=\exp \left[-\left(C_{2} / C_{1}\right)\right]$, and the antigen rate equation becomes:

$$
\frac{\mathrm{d} A}{\mathrm{~d} t}=a B-b \mathrm{e}^{r A}
$$

where $\alpha=b / a$. However, Eq. (A4) allows $A$ to be less than 0 at equilibrium when $B$ is $>0$. To insure that both $A$ and its derivative go to 0 as $B$ approaches 0 , we include $A$ in the loss term giving:

$$
\frac{\mathrm{d} A}{\mathrm{~d} t}=a B-b A \mathrm{e}^{r A}
$$

Eq. (A5) describes the situation in which antigen is secreted at a constant rate per bacterium, with removal increasing at a rate greater than exponential. The mechanisms for this increased removal include antigen autolysis (Griffith \& Lynch 1991) and increased antibody production. The exponential is surprising even with the 2 explanations above. One might instead expect loss follows a power function of $A$, with the exponent $p$ most likely 1 or 2 , representing either simple mass action or autolysis. The exponential observed in the data can also be explained by a decreasing production of antigen by bacteria with increasing antigen concentrations (autoinhibition), as in the following equation:

$$
\frac{\mathrm{d} A}{\mathrm{~d} t}=a B \mathrm{e}^{-\mathrm{r} A}-b \mathrm{~A}^{p}
$$

The negative exponential of antigen secretion with antigen concentration could result if the rate of antigen production were dependent upon the number of interactions between individual bacteria and antigen or upon the fraction of the bacterial cell surface with attached p57 and its breakdown products. It is possible that both an exponential decrease in antigen production and an exponential increase in antigen breakdown and removal occur simultaneously, resulting in:

$$
\frac{\mathrm{d} A}{\mathrm{~d} t}=a B \mathrm{e}^{-r_{1} A}-b A \mathrm{e}^{r_{2} A}
$$

Eqs. (A5), (A6) (with $p=1$ ), \& (A7) are equivalent when considering the equilibrium level of $A$ given any level of $B$. All the above equations can be generalized to:

$$
\frac{\mathrm{d} A}{\mathrm{~d} t}=a B \mathrm{e}^{-r_{1} \mathrm{~A}}-b A^{p} \mathrm{e}^{r_{2} A}
$$


Acknowledgements. This work was supported by the Bonneville Power Administration under contract 154-0001 (project 89-108). The authors would like to thank W. Nicholas Beer for discussions and assistance and 3 anonymous reviewers for their insights.

\section{LITERATURE CITED}

Balfry SK, Albright LJ, Evelyn TPT (1996) Horizontal transfer of Renibacterium salmoninarum among farmed salmonids via the fecal-oral route. Dis Aquat Org 25:63-69

Brown LL, Iwama GK, Evelyn TPT (1996) The effect of early exposure of coho salmon (Oncorhynchus kisutch) eggs to the p57 protein of Renibacterium salmoninarum on the development of immunity to the pathogen. Fish Shellfish Immunol 6:149-165

Bruno DW (1986) Histopathology of bacterial kidney disease in laboratory infected rainbow trout, Salmo gairdneri Richardson, and Atlantic salmon, Salmo salar L., with reference to naturally infected fish. J Fish Dis 9:523-527

Elliott DG, Barila TY (1987) Membrane filtration - fluorescent antibody staining procedure for detecting and quantifying Renibacterium salmoninarum in coelomic fluid of chinook salmon (Oncorhynchus tshawytscha). Can J Fish Aquat Sci 44:206-210

Elliott DG, Pascho RJ, Bullock GL (1989) Developments in the control of bacterial kidney disease of salmonid fishes. Dis Aquat Org 6:201-215

Evelyn TPT (1996) Infection and disease. In: Iwama G, Nakanishi $\mathrm{T}$ (eds) The fish immune system: organism, pathogen and environment. Academic Press, San Diego, p 339-366

Evelyn TPT, Ketcheson JE, Prosperi-Porta L (1984) Further evidence for the presence of the kidney disease bacterium (Renibacterium salmoninarum) and the failure of iodine, in the form of povidone-iodine, to reduce the intra-ovum infection rate in water-hardened eggs. J Fish Dis 7: 173-182

Evelyn TPT, Prosperi-Porta L, Ketcheson JE (1986) Experimental intra-ovum infection of salmonid eggs with Renibacterium salmoninarum and vertical transmission of the pathogen with such eggs despite their treatment with erythromycin. Dis Aquat Org 1:197-202

Evenden AJ, Grayson TH, Gilpin ML, Munn CB (1993) Renibacterium salmoninarum and bacterial kidney diseasethe unfinished jigsaw. Annu Rev Fish Dis 3:87-104

Flaño E, López-Fierro P, Razquin B, Kaattari SL, Vellena A (1996) Histopathology of the renal and splenic haemopoietic tissues of coho salmon Oncorhynchus kisutch experimentally infected with Renibacterium salmoninarum. Dis Aquat Org 24:107-115

Fryer JL, Sanders JE (1981) Bacterial kidney disease of salmonid fish. Annu Rev Microbiol 35:273-298

Griffiths SG, Lynch WH (1991) Instability of the major soluble antigen produced by Renibacterium salmoninarum. J Fish Dis 14:55-66

O'Farrell CL, Strom MS (1999) Differential expression of the virulence-associated protein p57 and characterization of

Editorial responsibility: David Bruno,

Aberdeen, Scotland, UK its duplicated gene msa in virulent and attenuated strains of Renibacterium salmoninarum. Dis Aquat Org 38: 115-123

O'Farrell CL, Elliott DG, Landolt ML (2000) Mortality and kidney histopathology of chinook salmon Oncorhynchus tshawytscha exposed to virulent and attenuated Renibacterium salmoninarum strains. Dis Aquat Org 43: 199-209

Pascho RJ, Mulcahy D (1987) Enzyme-linked immunosorbent assay for a soluble antigen of Renibacterium salmoninarum, the causative agent of salmonid bacterial kidney disease. Can J Fish Aquat Sci 44:183-191

Pascho RJ, Elliott DG, Mallett RW, Mulcahy D (1987) Comparison of five techniques for the detection of Renibacterium salmoninarum in adult coho salmon. Trans Am Fish Soc 116:882-890

Pascho RJ, Elliott DG, Streufert JM (1991) Brood stock segregation of spring chinook salmon Oncorhynchus tshawytscha by use of the enzyme linked immunosorbent assay (ELISA) and fluorescent antibody technique (FAT) affects the prevalence and levels of Renibacterium salmoninarum infection in progeny. Dis Aquat Org 12:25-40

Pascho RJ, Goodrich TD, McKibben CL (1997) Evaluation by enzyme-linked immunosorbent assay (ELISA) of Renibacterium salmoninarum bacterins affected by persistence of bacterial antigens. J Aquat Anim Health 9:99-107

Pascho RJ, Chase D, McKibben CL (1998) Comparison of the membrane-filtration fluorescent antibody test, the enzyme-linked immunosorbent assay and the polymerase chain reaction to detect Renibacterium salmoninarum in salmonid ovarian fluid. J Vet Diagn Invest 10:60-66

Sanders JE, Pilcher KS, Fryer JL (1978) Relation of water temperature to bacterial kidney disease in coho salmon (Oncorhynchus kisutch), sockeye salmon (O. nerka), and steelhead trout (Salmo gairdneri). J Fish Res Board Can 35:8-11

Senson PR, Stevenson RMW (1999) Production of the $57 \mathrm{kDa}$ major surface antigen by a non-agglutinating strain of the fish pathogen Renibacterium salmoninarum. Dis Aquat Org 38:23-31

Siegel DC, Congleton JL (1997) Bactericidal activity of juvenile chinook salmon macrophages against Aeromonas salmonicida after exposure to live or heat-killed Renibacterium salmoninarum or to soluble proteins produced by $R$. salmoninarum. J Aquat Anim Health 9:180-189

Turaga PSD, Weins GD, Kaattari SL (1987) Analysis of Renibacterium salmoninarum antigen production. Fish Pathol 22:209-214

Weins GD, Kaattari SL (1999) Bacterial kidney disease (Renibacterium salmoninarum). In: Woo PTK, Bruno DW (eds) Fish diseases and disorders, Vol 3. Viral, bacterial and fungal infections. CAB International, New York, p 269-301

Weins GD, Chein MS, Winton JR, Kaattari SL (1999) Antigenic and functional characterization of p57 produced by Renibacterium salmoninarum. Dis Aquat Org 37:43-52

Wood PA, Kaattari SL (1996) Enhanced immunogenicity of Renibacterium salmoninarum in chinook salmon after removal of the bacterial cell surface-associated $57 \mathrm{kDa}$ protein. Dis Aquat Org 25:71-79

Submitted: May 5, 2001; Accepted: February 25, 2002

Proofs received from author(s): August 5, 2002 